\title{
Near-Facility
}

\section{Environmental Monitoring Quality Assurance Project Plan}

Prepared for the U.S. Department of Energy Assistant Secretary for Environmental Management

Project Hanford Management Contractor for the

U.S. Department of Energy under Contract DE-AC06-96RL13200

\section{Fluor Hanford}

Richland, Washington 


\section{LEGAL DISCLAIMER}

This report was prepared as an account of work sponsored by an agency of the United States Government. Neither the United States Government nor any agency thereof, nor any of their employees, nor any of their contractors, subcontractors or their employees, makes any warranty, express or implied, or assumes any legal liability or responsibility for the accuracy. completeness, or any third party's use or the results of such use of any information, apparatus, product, or process disclosed, or represents that its use would not infringe privately owned rights. Reference herein to any specific commercial product, process, or service by trade name, trademark, manufacturer, or otherwise, does not necessarily constitute or imply its endorsement, recommendation, or favoring by the United States Government or any agency thereof or its contractors or subcontractors. The views and opinions of authors expressed herein do not necessarily state or reflect those of the United States Government or any agency thereof.

This report has been reproduced from the best available copy. Available in paper copy and microfiche.

Available electronically at http://wnw.doe.gov/bridge. Available for a processing fee to the U.S. Department of Energy and its contractors, in paper, from:

U.S. Department of Energy

Office of Scientific and Technical information

P.O. Box 62

Oak Ridge, TN 37831-0062

phone; 865-576-8401

fax: 865-576-5728

email: reports Qadonis.osti.gov(423) 576-8401

Available for sale to the public, in paper, from:

U.S. Department of Commerce

National Technical Information Service

5285 Port Royal Road

Springfield, VA 22161

phone: 800-553-6847

fax: 703-605-6900

email: orders (2) ntis.fedworld.gov

online ordering: http:/hww.ntis.gov/ordering.htm 


\section{Near-Facility Environmental Monitoring Quality Assurance Project Plan}

S. M. McKinney

Waste Management Technical Services

Date Published

May 2000

Prepared for the U.S. Department of Energy

Assistant Secretary for Environmental Management

Project Hanford Management Contractor for the

U.S. Department of Energy under Contract DE-AC06-96RL13200

Fluor Hanford

P.0. Box 1000

Richland, Washington

$\frac{\text { Chiv Yratteinghand s-30-00 }}{\text { Release Approval }}$ 
This page intentionally left blank. 
HNF-EP-0538-5

NEAR-FACILITY ENVIRONMENTAL MONITORING QUALITY ASSURANCE PROJECT PLAN

Prepared by:

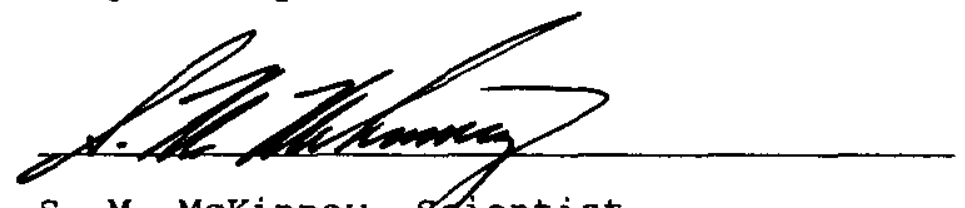

S. M. Mckinney, Scientist

Environmental Monitoring \& Investigations waste Management Technical Services

Reviewed and

Approved by:

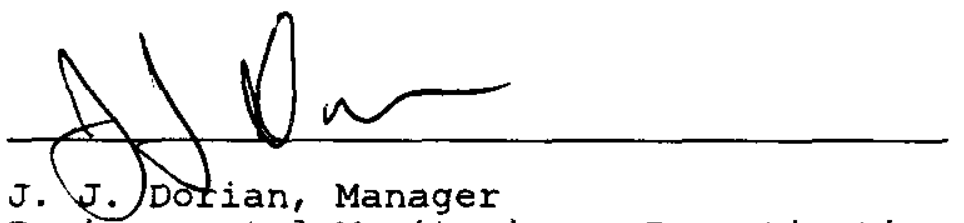

Environmental Monitoring \& Investigations Waste Management Technical Services

Approved by:

Septal

D. J. Moak, Director

Operations Division

waste Management Technical Services

Haluial

M. F. Nicol, Manager Quality Assurance

Waste Management Technical Services.

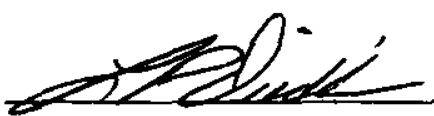

L. P. Diediker

Monitoring and Reporting

Fluor Project Hanford
Date: stor/ en

Date: $5 / 17 / 00$

Date: $\quad 5-24-00$

Date: $5 / 24 / 00$

Date: $\quad 5=30-\infty$

i 
HNF-EP-0538-5

This page intentionally left blank. 
HNF-EP-0 $538-5$

QUAIITY ASSURANCE PROJECT PIAN

\title{
s. M. Makinney
}

\begin{abstract}
This Quality Assurance Project Plan addresses the quality assurance requirements for the activities associated with the preoperational and near-facility environmental monitoring directed by Waste Management Technical services and supersedes HNF-EP-0538-4. This plan applies to all sampling and monitoring activities performed by Waste Management Technical services in implementing near-facility environmental monitoring at the Hanford site.
\end{abstract}

This Quality Assurance Project Plan is required by U.S. Department of Energy Order 5400.1 (DOE 1990) as a part of the Environmental Monitoring Plan (DOE-RL 1997) and is used to define:

- Environmental measurement and sampling locations used to monitor environmental contaminants near active and inactive facilities and waste storage and disposal sites

- Procedures and equipment needed to perform the measurement and sampling

- Frequency and analyses required for each measurement and sampling location

- Minimum detection level and accuracy

- Quality assurance components

- Investigation levels. 


\section{HNF-EP-0538-5}

Near-facility environmental monitoring for the Hanford site is conducted in accordance with the requirements of U.S. Department of Energy Orders 5400.1 (DOE 1990), 5400.5 (DOE 1993), 5484.1 (DOE 1990), and 435.1 (DOE 1999), and DOE/EH-O173T (DOE 1991). It is Waste Management Technical Services' objective to manage and conduct near-facility environmental monitoring activities at the Hanford site in a cost-effective and environmentally responsible manner that is in compliance with the letter and spirit of these regulations and other environmental regulations, statutes, and standards. 
HNF-EP-0538-5

CONTENTS

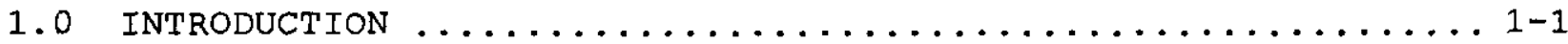

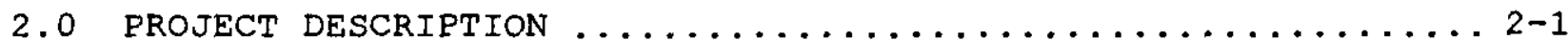

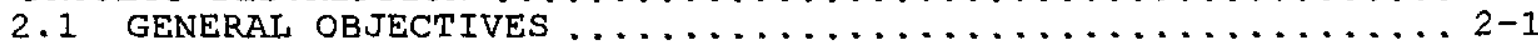

2.2 MONITORING ACTIVITIES DESCRIPTION ................ 2-2

2.3 APPLICABILITY TO WASTE MANAGEMENT TECHNICAL SERVICES

QUALITY ASSURANCE PROGRAM ................... 2-3

3.0 PROJECT ORGANIZATION AND RESPONSIBILITIES $\ldots \ldots \ldots \ldots \ldots \ldots \ldots$

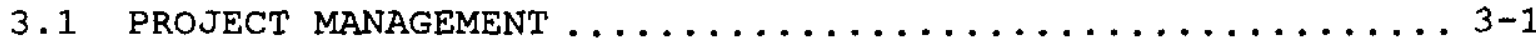

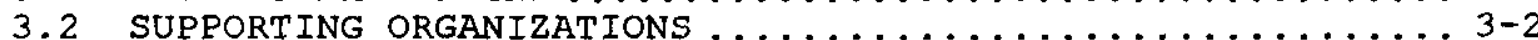

3.3 ANALYTICAL LABORATORIES ......................

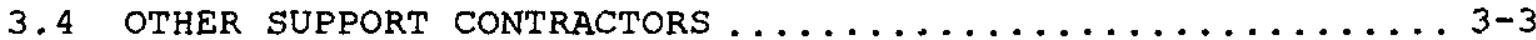

4.0 QUALITY ASSURANCE OBJECTIVES FOR MEASUREMENTS .......... 4-1

4.1 ANALYTES OF INTEREST AND ANALYTICAL METHOD SELECTION . . . 4-1

4.2 CONTRACTUAL QUANTITATION IIMITS AND RANGES FOR

ANALYTICAL

PRECISION AND ACCURACY ..................... 4-1

4.3 REPRESENTATIVENESS, COMPLETENESS, AND COMPARABILITY . . . 4-2

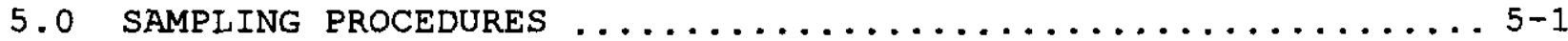

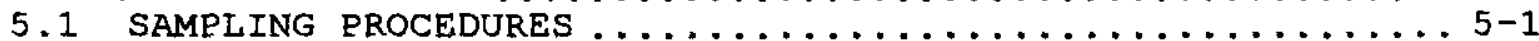

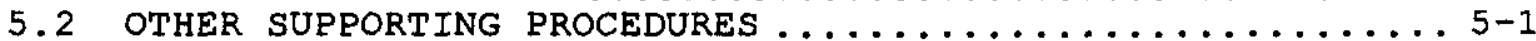

5.3 PROCEDURE APPROVALS AND CONTROL ................ 5-1

5.3.1 Waste Management Technical Service Procedures.... . 5-1

5.3.2 Participant Contractor/Subcontractor Procedures... 5-1

5.4 PROCEDURE ADDITIONS AND CHANGES ................. $5-2$

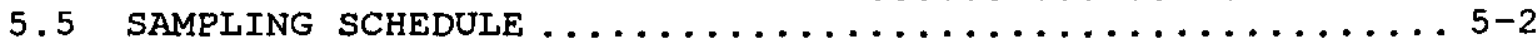

6.0 SAMPLE CUSTODY $\ldots \ldots \ldots \ldots \ldots \ldots \ldots \ldots \ldots \ldots \ldots \ldots \ldots \ldots \ldots \ldots$

7.0 CALIBRATION PROCEDURES $\ldots \ldots \ldots \ldots \ldots \ldots \ldots \ldots \ldots \ldots \ldots \ldots \ldots \ldots \ldots . \ldots \ldots$

8.0 ANALYTICAL PROCEDURES $\ldots \ldots \ldots \ldots \ldots \ldots \ldots \ldots \ldots \ldots \ldots \ldots \ldots$

9.0 MONITORING AND REPORTING CRITERIA ................. $9-1$

10.0 DATA REDUCTION, VALIDATION, AND REPORTING ........... 10-1 10.1 DATA REDUCTION AND DATA PACKAGE PREPARATION .........10-1

10.2 VALIDATION . ............................ 10-1

10.3 EINAL REVIEW AND RECORDS MANAGEMENT CONSIDERATIONS ... 10-2

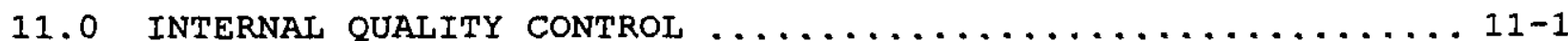

11.1 REPLICATE SAMPLING ....................... 11-1

11.2 LABORATORY ANALYSES ..................... 11-1

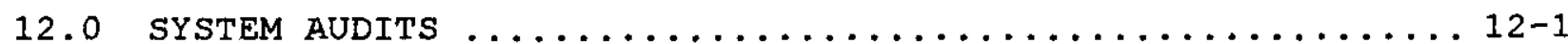

13.0 PREVENTIVE MAINTENANCE $\ldots \ldots \ldots \ldots \ldots \ldots \ldots \ldots \ldots \ldots \ldots \ldots$

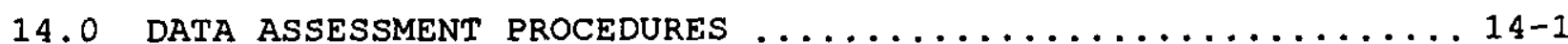


HNF-EP-0 $538-5$

CONTENTS (cont)

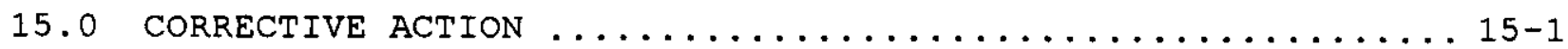

16.0 QUALITY ASSURANCE REPORTS $\ldots \ldots \ldots \ldots \ldots \ldots \ldots \ldots \ldots \ldots$

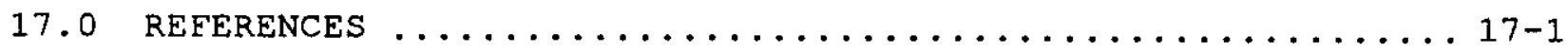

\section{LIST OF TABIES}

4-1 Preferred Analytical Methods ..................... 4-3

4-2 Supporting Procedures for the Near-Facility

Environmental Monitoring Program ..................4-5 


\section{LIBT OF TERMS}

BHI

CBRCS

CERCLA

CER

CHG

DOE

DOE RI

EMP

EPA

ERC

FEMP

$\mathrm{EH}$

EPH

HAS

LIW

MDC

ORP

PNNL,

$Q A$

QAPjP

$Q \mathrm{C}$

RC

RL

RPP

SESP

WDOH

WMTS
Bechtel Hanford, Inc.

Component Based Recall Calibration System

Comprehensive Environmental Response

Compensation and Liability Act of 1980

Code of Federal Regulations

CH2M Hill Hanford Group

U.S. Department of Energy

Richland operations office

Environmental Monitoring Plan

U.S. Environmental Protection Agency

Environmental Restoration contractor

facility effluent monitoring plan

Fluor Hanford

Fluor Project Hanford

Hanford Analytical Services

low-level waste

minimum detectable concentrations

office of River Protection

Pacific Northwest National Laboratory

quality assurance

quality assurance project plan

quality control

Radiological Control

U.S. Department of Energy, Richland Operations River Protection Project

Site Environmental surveillance program

washington State Department of Health

Waste Management Technical Services 
HNF-EP-0538-5

This page intentionally left blank. 


\section{HNF-EP-0538- 5}

\subsection{INTRODUCTION}

The U.S. Department of Energy (DOE) Order 5400.1, General Environmental Protection Program (DOE 1988), required DOE sites to prepare an environmental monitoring plan (EMP). The revised Environmental Monitoring Plan, DOE/RL 91-50, Revision 2 (DOE-RL 1997), was issued on November 9, 1997.

According to the guidance provided in DOE order 5400.1 (DOE 1988), each DOE site, facility, or activity that uses, generates, releases, or manages significant quantities of hazardous materials shall provide a written EMP. This EMP must identify and discuss two major activities: effluent monitoring and environmental surveillance.

This quality assurance project plan (QAPJP) addresses the quality assurance $(Q A)$ implementation of near-facility environmental monitoring as part of the overall EMP. 
HNF-EP-0538-5

This page intentionally left blank. 
HNF-EP-0538-5

\subsection{PROJECT DESCRIPTION}

\subsection{GENERAL OBJECTIVES}

Near-facility environmental monitoring provides facility-specific monitoring to protect the environment adjacent to facilities under the responsibility of the Fluor Project Hanford (FPH), River Protection Project(RPP) or Environmental Restoration Contractor (ERC), to ensure compliance with FPH, RPP, and ERC requirements and local, state, and federal environmental regulations.

The objectives of near-facility environmental monitoring are to evaluate the following:

- Compliance with DOE, the U.S. Environmental Protection Agency (EPA), the Washington State Department of Ecology (Ecology), the Washington state Department of Health (WDOH), and internal FPH and ERC environmental radiation protection requirements and guides

- Performance of radioactive waste confinement systems

- Trends of radioactive materials in the environment at and adjacent to nuclear facilities and waste disposal sites.

Specifically, near-facility environmental monitoring is developed to:

- Monitor inactive, existing, and new low-level waste (JLW) disposal sites to assess both radiological and nonradiological hazards (DOE order 435.1).

- Determine the effectiveness of effluent treatment and controls in reducing effluents and emissions (DOE/EH-0173T and $\mathrm{DOE} / \mathrm{EV} / 1830-\mathrm{T} 5)$.

- Detect and quantify unplanned releases (DOE/EH-0173T) [Title 40 Code of Federal Regulation (CFR) Part 302] [Washington Administrative Code (WAC) 173-303-145] (DOE Orders 5000.3B and 5484.1 ).

- Monitor fugitive emissions and diffuse sources from contaminated areas for compliance with the "National Emission Standards for Hazardous Air Pollutants" (NESHAP) (40 CFR 61), (DOE/EH-0173T), Toxic Air Emissions Inventory (40 CFR 265, Subparts AA and B13), state Operating Permit Program (40 CFR 70), and Source Registration (WAC 246 and 247).

- Monitor all surplus facilities before and during decontaminating or decommissioning (DOE order 435.1).

- Monitor new and existing sites, processes, and facilities for potential impacts and releases (DOE orders 5400.1 and 5484.1 , and DOE/EH-0173T).

- Monitor and assess radioactive contamination and potential 
HNF-EP-0538- 5

exposure to employees and the public (DOE Orders 5400.1, 5400.5 and 10 CFR 835 Occupational Radiation Protection).

The purpose and justification for near-facility environmental monitoring is contained in HNF-PRO-454, Inactive Waste sites and HNFPRO-455, Solid Waste Management.

The primary justification for near-facility environmental monitoring includes the following:

- Near-facility environmental monitoring provides a level of assurance to FPH, RPP, and ERC that the effluent and contamination controls for the various facilities and waste sites are effective.

- Near-facility environmental monitoring monitors a diversity of operations, activities, and programs managed by several different FPH contractors, RPP, and ERC organizations. Accordingly, program direction and integration for nearfacility environmental monitoring activities are needed to ensure consistency, technical quality, and cost effectiveness.

- A secondary aspect of near-facility environmental monitoring is additional assurance beyond that provided by the occupational Health and Safety program that it is acceptable to work on site and for visitors to safely tour the site.

It is the objective of WMTS to manage and conduct near-facility environmental monitoring activities at the Hanford Site in a costeffective and environmentally responsible manner that is in compliance with the letter and spirit of applicable environmental statutes, regulations, and standards. Near-facility environmental monitoring shall monitor fugitive emissions and diffuse sources from radioactively contaminated areas.

This QAPJP identifies the requirements and specifies the procedures used to implement near-facility environmental monitoring. Responsibilities are defined for those WMTS personnel involved in environmental monitoring. WMTS personnel shall use this QAPjP to ensure that near-facility environmental monitoring is performed in a consistent manner.

\subsection{MONITORING ACTIVITIES DESCRIPTION}

The specific near-facility environmental monitoring activities performed by WMTS are defined in HNE-PRO-454, Inactive Waste Sites, HNF-PRO-455, Solid Waste Management, and WMTS-OEM-001, WMTS Operational Environmental Monitoring, and generally fall into one or more of the following four categories:

- Monitoring of inactive and active waste storage and disposal sites as well as unplanned release sites

- Preoperational monitoring of new or modified facilities that have the potential to adversely impact the environment 
HNF-EP-0538-5

- Monitoring of operating or standby facilities

- Monitoring of facilities in the process of demolition or remediation.

The monitoring scope for these categories includes the collection of ambient air, water, sediment, aquatic vegetation, soil, biota, external radiation measurements, and radiological surveys.

\subsection{APPLICABIIITY TO WASTE MANAGEMENT TECHNICAI SERVICES QUAIITY ASSURANCE PROGRAM}

This QAPJP applies specifically to the sampling and analysis activities, and monitoring performed for all near-facility environmental monitoring activities conducted and/or directed by WMTS. This plan is subordinate to the Quality Assurance Program Plan for Project Hanford Management Contract Work, WMTS-QAPP-001.

This QAPJP is prepared in accordance with the guidance of Interim Guidelines and Specifications for Preparing Quality Assurance Project Plans, QAMS-005/80 (EPA 1983), and "Quality Assurance Methods," 40 CFR 61, Appendix B, Method 114, as required by the Environmental Regulatory Guide for Radiological Effluent Monitoring and Environmental Surveillance, DOE/EH-0173T. It describes the means selected to implement the overall $Q A$ program requirements defined in the HNF-MP-599, Project Hanford Quality Assurance Program Description. The implementing procedures, plans, and instructions are appropriate for the control of near-facility environmental monitoring, which requires compliance with DOE, EPA, state, and local requirements.

The QAPjP uses a matrix of procedural resources from facility or Hanford Site manuals used in near-facility environmental monitoring. This QAPJP shall be reviewed and updated as required when changes are made in near-facility environmental monitoring. Distribution and revision control of this plan shall be in compliance with HNF-MP-599, Project Hanford Quality Assurance Program Description.

Review/approval personnel indicated on the title page of the document and other individuals designated by Environmental Monitoring and Investigations (EM\&I) shall have distribution and revision control. Plans and procedures referenced in the QAPjP are available on request for regulatory review.

Near-Facility Environmental Monitoring (NFEM) activities and major procurements in support of the environmental monitoring program will be generally controlled in accordance with HNF-MP-599, Project Hanford Quality Assurance Program Description. NFEM activities such as minor procurements, program assessments, records management, etc., will follow the requirements of WMTS-QAM-001, Quality Assurance Manual. Preoperational environmental monitoring and environmental monitoring outside the NFEM contracts will be governed by the WMTSQAM-001, Quality Assurance Manual and/or those controlling QA requirements identified in the contract documents. 
HNF-EP-0538- 5

This page intentionally left blank. 
HNF-EP-0538-5

\subsection{PROJECT ORGANIZATION AND RESPONSIBILITIES}

\subsection{PROJECT MANAGEMENT}

Environmental Monitoring and Investigations within the Environmental Services Organization of Waste Management Technical Services has the responsibility for specifying near-facility environmental monitoring requirements. Responsibilities of essential personnel are described below.

- Near-Field Monitoring. The Near-Field Monitoring team within Environmental Monitoring and Investigations has the responsibility to plan, direct, and verify near-facility environmental monitoring at FPH, RPP, and ERC facilities, unplanned release sites, and associated active and inactive waste storage and disposal sites as required to ensure compliance to environmental requirements.

Near-Field Monitoring acts as the technical liaison between FPH facilities, other DOE contractors, regulators, and other interested parties. Near-Field Monitoring also provides technical support for operational environmental sampling and analysis. Near-Field Monitoring performs trend analysis and prepares annual near-facility environmental monitoring reports for distribution to FPH, RPP, and ERC facilities, DOE contractors, regulators, and other interested parties. Near-Field Monitoring assigns sample numbers and identification numbers for each sample point. The maintenance of the air samplers, including the repair or replacement of defective parts, is directed by Near-Field monitoring. Near-Field Monitoring maintains the permanent records of near-facility environmental monitoring samples. Near-Field Monitoring also ensures that the QAPJP and associated documentation are updated.

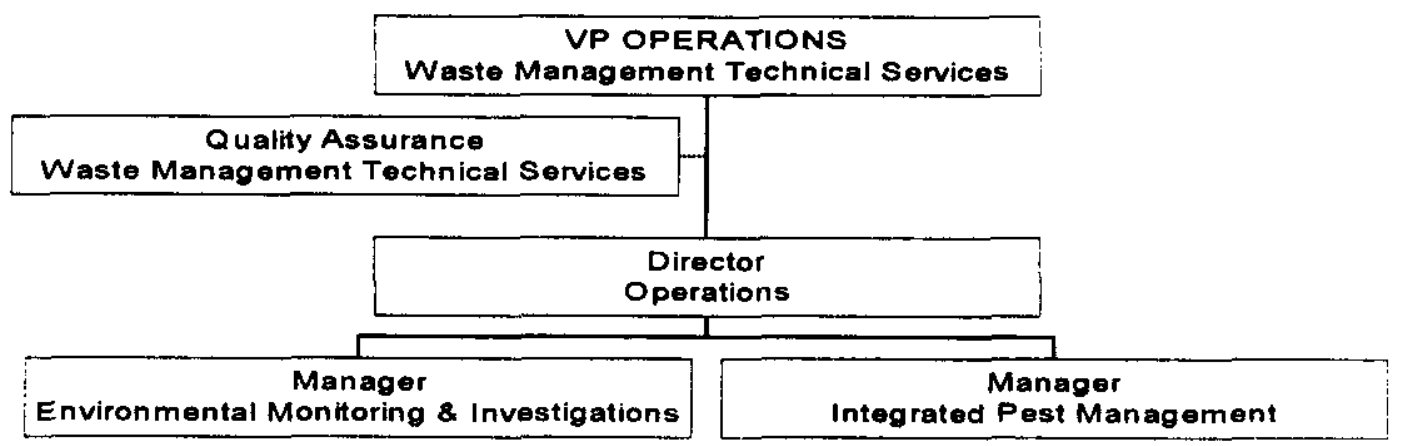

- Integrated Pest Management. Integrated Pest Management contains two organizational functions, Pest Control and Vegetation Management. These two functions work closely with Near-Facility Monitoring in identifying and controlling the spread of contamination through biological vectors. In February 1999, an integrated biological control program was developed under the direction of DOE/RL with Technical Authority being assigned to Fluor Hanford and Project management being assigned to DynCorp Tri-Cities Services, Inc. 
- Radiological Control/site surveillance. The Site Support Services Radiological Control Group has the responsibility to provide sampling and monitoring support as defined in near-facility environmental monitoring. The Bechtel Hanford, Inc., Radiological Monitoring and Environmental Support Group has the responsibility to provide radiation surveys of inactive waste sites and facilities under its control.

\subsection{SUPPORTING ORGANIZATIONS}

- Facility Manager. The FPR, RPP, and ERC facility managers have the responsibility to maintain their facilities in an environmentally safe condition, be responsive to environmental problems or concerns raised about their facilities, and provide corrective action to these problems or concerns.

- Quality Assurance. Provides quality-engineering support to meet procurement control, document approval, surveiliance, and auditing needs.

- Monitoring and Reporting. Monitoring and Reporting has the responsibility to oversee and verify the environmental radioactivity and chemical emission monitoring program at EPH facilities as required ensuring compliance with environmental regulations.

- Procurement. The procurement organization obtains services and/or contracts in accordance with purchase requisitions, purchase orders, drawings, contracts, specifications, or instructions used to define requirements for a purchase.

- Environmental Integration. These personnel provide guidance in interpretation of all regulations and coordination with pertinent regulatory agencies, establish, and maintain the environmental series of procedures, HNF-PRO-450 through HNFPRO-462.

- Analytical services. Provides data package validation as requested by EM\&I.

- T-Plant maintenance. Provides maintenance, repairs, and replaces defective parts on the environmental air samplers as directed by EM\&I.

\subsection{ANAIYTICAL IABORATORIES}

Analytical samples will be transported to an approved FPH participant contractor or subcontractor laboratory for radiological and/or chemical analysis. For participant contractors or subcontractors, applicable quality requirements of this QAPjP shall be invoked as part of the approved applicable work order, letter of instruction, or procurement document. Laboratories are to submit their analytical methods and internal QA Program to Hanford Analytical Services (HAS) for review and approval before use. 
Analysis of ambient air samples collected as part of the NFM shall meet the Radioanalytical QA requirements of EPA Method 114.

At the direction of EM\&I, laboratories may be procured for split (performance audit) sample analysis. Participant contractor or subcontractor laboratories will be subject to source surveillance with Quality systems participation, in compliance with HNF-MP-599, Project Hanford Quality Assurance Program Description; HNF-PRO-210, Records Management Program Standards; HNF-PRO-222, Quality Assurance Records Standards; HNF-PRO-224, Document Control Program Standards; HNE-PRO-261, Quality Assurance Program Plans; HNF-PRO-268, Control of Purchased Items and Equipment: HNF-PRO-298, Nonconforming Item Reporting and Control; and/or WMNW-PCM-001, Procurement Manual.

\subsection{OTHER SUPPORT CONTRACTORS}

The EM\&I program may procure the services of other subcontractors to support any or all of the activities addressed by this QAPJP. Such activities shall be in compliance with FPH approved QA plans and/or procedures, subject to the controls of HNF-MP-599, Project Hanford Quality Assurance Program Description and/or WMTS-QAM-001, Quality Assurance Manual. 
HNF-EP-0538-5

This page intentionally left blank. 


\subsection{QUAIITY ASSURANCE OBJECTIVES FOR MEASUREMENTS}

The $Q A$ objectives for measurements generally applicable to nearfacility environmental monitoring under the purview of this QAPjP are related primarily to the following:

- Defining appropriate methods for sampling and analysis for the required analytes of interest

- Defining quantitation limits and values for analytical precision and accuracy appropriate for the purposes of all near-facility environmental monitoring.

- Defining data representativeness, completeness, and comparability in terms applicable to near-facility environmental monitoring.

Detailed discussions of the analytes of interest and analytical methods are provided in Table 4-1. Specific data quality needs for individual investigations shall be addressed at the time of the need. other measurement considerations, accuracy requirements, units, and data recording/reporting protocols for instruments supporting nearfacility environmental monitoring and other types of special monitoring investigations shall be specified in the applicable procedures discussed herein and in the laboratory statement of work. The statement of work is as follows: HNF-EP-0835-5, Statement of Work for Services Provided by the Waste Sampling and Characterization Facility for Effluent and Environmental Monitoring Program During Calendar Year 1999, (Diediker 1999).

All near-facility environmental monitoring sampling and monitoring activities shall meet the applicable regulatory requirements of the DOE, EPA, and DOH identified in the sitewide NESHAP QAPJP and follow the guidance of the following procedures:

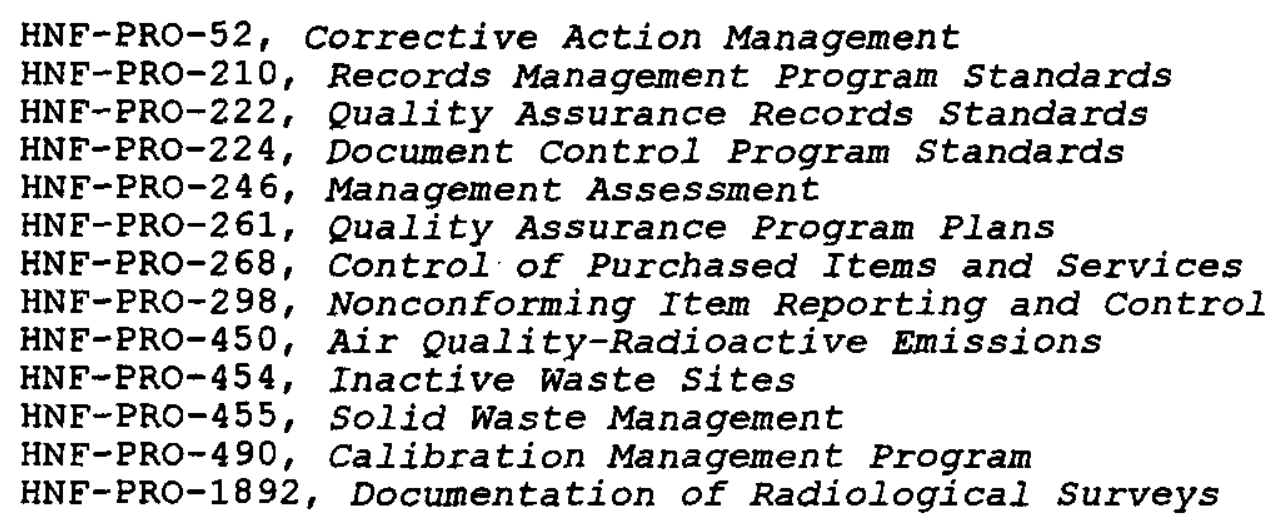

Air samples collected in support of near-facility environmental monitoring shall meet the Radioanalytical QA requirements of EPA Method 114 used to report radioactive air emissions per 40 CFR 61, Subpart $\mathrm{H}$.

Data handling, reporting, and procurement activities will be performed at a Quality Level III. The performance of the radiological monitoring is subject to 10CFR830.120, Quality Assurance Requirements, and the enforcement actions under 10CFR820, General

$$
\text { 4-1 }
$$


Statement of Enforcement Policy.

\subsection{ANALYTES OF INTEREST AND ANALYTICAL METHOD SELECTION}

Table 4-1 identifies potential analytes of interest and corresponding analytical reference methods for operational environmental sampling and monitoring at the Hanford site. The list of analytes specifies reference methods selected from the appropriate EPA and DOE guidance documents. (See notes $a, d, e, f, g$, and $h$ of Table 4-1.) Where options have been suggested or implied, the more reliable methods have been selected.

The 222-s Laboratory typically performs radiological analyses of all samples submitted. The Waste sampling and Characterization Facility (WSCF) laboratory performs analyses of radioactive and nonradioactive constituents in air, liquid, soil, vegetation and aquatic soil and vegetation associated with near-facility environmental monitoring. Pacific Northwest National Laboratories (PNNL) reads the dose on the thermal luminescent dosimeters.

\subsection{CONTRACTUAL QUANTITATION IIMITS AND RANGES FOR ANALYTICAL PRECISION AND ACCURACY}

The performance of the analytical laboratory or laboratories providing support to near-facility environmental monitoring shall be subject to EPA-established method and analyte-specific quantitation limits and ranges for precision and accuracy (EPA 1972, EPA 1977). These parameters are presented as target values that FPH and the proposed laboratory must adjust and/or confirm and accept before the final approval of an associated subcontract, work order, or statement of work.

\subsection{REPRESENTATIVENESS, COMPLETENESS, AND COMPARABILITY}

The specifications of location and sampling intervals are identified in HNF-SP-0098-11, Routine Environmental Monitoring Schedule, Calendar Year 2000 and in WMTS-OEM-001, WMTS Operational Environmental Monitoring. The qualitative goals for data representativeness are addressed in HNF-EP-0835-5, statement of work for Services Provided by the Waste Sampling and Characterization Eacility for the Effluent and Environmental Monitoring Program. Completeness objectives for near-facility environmental monitoring shall require that the contractually or procedurally established requirements for the precision and accuracy be met for at least 90 percent of the requested determinations on an annual basis for each laboratory conducting analyses. This means that precision and accuracy for all operational environmental monitoring data shall be at least 90 percent effective, accurate, and precise overall.

Failure to meet this criterion shall be documented in data summary reports and shall be considered in the validation process. Corrective action measures using specific procedures shall be initiated by EM\&I, HAS or $Q A$, as appropriate. Approved analytical procedures shall require the use of the reporting techniques and units consistent with the EPA reference methods listed in Table 4-1 to facilitate data-set comparability in terms of precision and accuracy. 
HNF-EP-0538-5

Table 4-1. Preferred Analytical Methods.

\begin{tabular}{|c|c|c|c|}
\hline $\begin{array}{l}\text { Analytical } \\
\text { Category }\end{array}$ & $\begin{array}{l}\text { Analyte of } \\
\text { Interest }\end{array}$ & $\begin{array}{c}\text { Standard EPA } \\
\text { Reference Method }\end{array}$ & $\begin{array}{l}\text { Analytical } \\
\text { Method }^{c}\end{array}$ \\
\hline \multirow[t]{3}{*}{ Ions/Anions } & Nitrate & $352.1^{d}$ & $\mathrm{~b}$ \\
\hline & Nitrite & $354.1^{c}$ & $\mathrm{~b}$ \\
\hline & $\begin{array}{l}\text { Ph/Total } \\
\text { Dissolved } \\
\text { Solids (TSD) }\end{array}$ & $9045^{\circ}$ & $\mathrm{b}$ \\
\hline \multirow[t]{22}{*}{ Radionuclides } & & & \\
\hline & Gross Alpha ${ }^{K}$ & $9310^{2}$ & $\mathrm{~b}$ \\
\hline & Gross Beta ${ }^{3}$ & $9310^{a}$ & $\mathrm{~b}$ \\
\hline & $\begin{array}{l}\text { Uranium } \\
(238,239,240)\end{array}$ & $00-07^{1}$ & $\mathrm{~b}$ \\
\hline & $\begin{array}{l}\text { Uranium } \\
233,234\end{array}$ & $00-07^{2}$ & $\mathrm{~b}$ \\
\hline & Uranium 235 & $00-07^{\mathrm{T}}$ & $\mathrm{b}$ \\
\hline & $\begin{array}{l}\text { Plutonium } \\
(238,239,240)\end{array}$ & $00-07^{\mathrm{e}}$ & $\mathrm{b}$ \\
\hline & Plutonium 241 & $00-07^{\bar{E}}$ & $\mathrm{~b}$ \\
\hline & $\begin{array}{l}\text { Americium } \\
241,243\end{array}$ & $A M-01^{e}$ & $\mathrm{~b}$ \\
\hline & $\begin{array}{l}\text { Strontium } \\
89 / 90\end{array}$ & SR-0 $5^{T}$ & $\mathrm{~b}$ \\
\hline & Tritium & $707^{h}$ & $\mathrm{~b}$ \\
\hline & Technetium 99 & EC-186 & $\mathrm{b}$ \\
\hline & Cesium 137 & NA & $\mathrm{b}$ \\
\hline & Cesium 134 & NA & $\mathrm{b}$ \\
\hline & Cesium 135 & NA & $\mathrm{b}$ \\
\hline & Iodine 129 & NA & $\mathrm{b}$ \\
\hline & Cerium 144 & NA & $\mathrm{b}$ \\
\hline & Carbon 14 & NA & $\mathrm{b}$ \\
\hline & Ruthenium 103 & NA & $\mathrm{b}$ \\
\hline & Ruthenium 106 & $\mathrm{NA}$ & $\mathrm{b}$ \\
\hline & Selenium & NA & $\mathrm{b}$ \\
\hline & Cobalt $60 / 58$ & $\mathrm{NA}$ & b \\
\hline
\end{tabular}


HNF-EP-0538-5

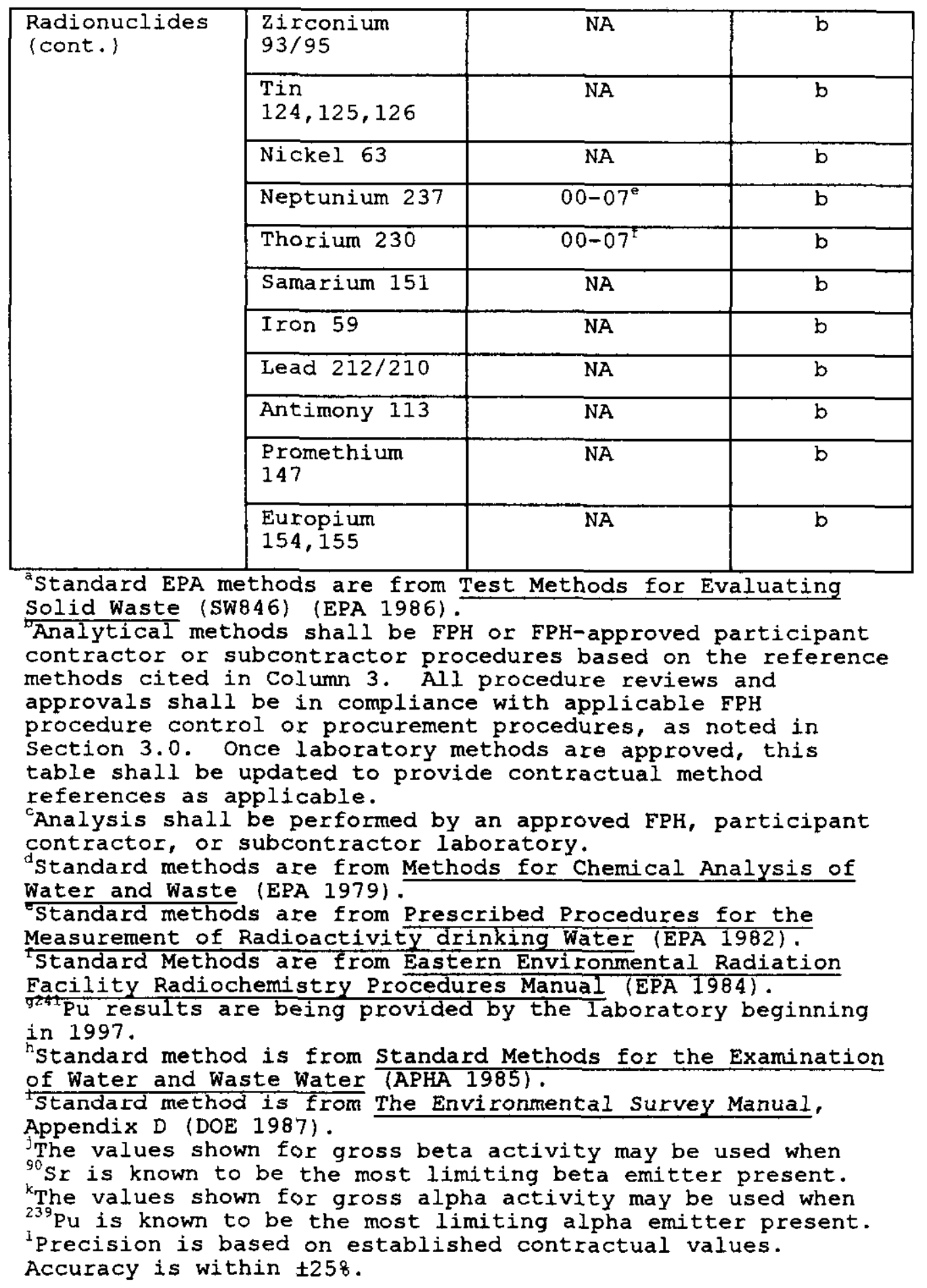


Table 4-2. Supporting Procedures for the Near-Facility Environmental Monitoring Program.

\begin{tabular}{|c|c|c|}
\hline Procedure & Procedure Number & Title \\
\hline $\begin{array}{l}\text { Chain of Custody } \\
\text { and Sample } \\
\text { Packaging and } \\
\text { Shipping }\end{array}$ & $\begin{array}{l}\text { WMTS-OEM-001, Section } 4 \\
\text { HNF-IP-0718 }\end{array}$ & $\begin{array}{l}\text { Procedure } \\
\text { Verification } \\
\text { Various Titles (See } \\
\text { Section } 17.0 \text { ) }\end{array}$ \\
\hline \multirow[t]{8}{*}{$\begin{array}{l}\text { Sampling and } \\
\text { Monitoring }\end{array}$} & $\begin{array}{l}\text { WMTS-OEM-001, Section } 5 \\
\text { HNF-IP-0718 }\end{array}$ & $\begin{array}{l}\text { Air Sampling } \\
\text { Various Titles }\end{array}$ \\
\hline & $\begin{array}{l}\text { WMTS-OEM-001, Section } 6 \\
\text { HNF-IP-0718 }\end{array}$ & $\begin{array}{l}\text { Soil Sampling } \\
\text { Various Titles }\end{array}$ \\
\hline & $\begin{array}{l}\text { WMTS-OEM-001, Section } 7 \\
\text { HNE-IP-0718 }\end{array}$ & $\begin{array}{l}\text { Vegetation Sampling } \\
\text { Various Titles }\end{array}$ \\
\hline & $\begin{array}{l}\text { WMTS-OEM-001, Section } 8 \\
\text { HNE-IP-0718 }\end{array}$ & $\begin{array}{l}\text { Animal Sampling } \\
\text { Various Titles }\end{array}$ \\
\hline & $\begin{array}{l}\text { WMTS-OEM-001, section } 9 \\
\text { HNE-IP-0718 }\end{array}$ & $\begin{array}{l}\text { Surface water } \\
\text { Sampling } \\
\text { Various Titles }\end{array}$ \\
\hline & $\begin{array}{l}\text { WMTS-OEM-001, Section } 11 \\
\text { HNF-IP-0718 }\end{array}$ & $\begin{array}{l}\text { Background } \\
\text { Radiation } \\
\text { Various Titles }\end{array}$ \\
\hline & $\begin{array}{l}\text { WMTS-OEM-001, Section } 12 \\
\text { HNF-IP-0718 } \\
\text { BHI-EE-002 }\end{array}$ & $\begin{array}{l}\text { Radiological } \\
\text { Surveys } \\
\text { Various Titles } \\
\text { Various Titles }\end{array}$ \\
\hline & $\begin{array}{l}\text { WMTS-OEM-001, section } 13 \\
\text { HNE-IP-0718 }\end{array}$ & $\begin{array}{l}\text { Special and } \\
\text { Emergency Sampling } \\
\text { Various Titles }\end{array}$ \\
\hline Calibration & HNF-IP-0718, HNF-PRO-490 & Various Titles \\
\hline
\end{tabular}


HNF-EP-0 $538-5$

This page intentionally left blank. 
HNF-EP-0538-5

\section{0 SAMPIING PROCEDURES}

\subsection{SAMPIING PROCEDURES}

Sampling activities, equipment, material, and containers will be subjected to field screening (i.e., radiological survey and quality control check of transportation documentation) for radioactivity. This screening shall be in compliance with the requirements governing radiation permits to ensure that samples are transported only to appropriately equipped and licensed laboratories. All environmental monitoring sampling conducted in support of near-facility environmental monitoring will be performed in a manner that provides representative samples of radioactive materials in near-field environmental media from operations at the Hanford site.

\subsection{OTHER SUPPORTING PROCEDURES}

Except for the analytical chemistry procedures specified in Table 4-1, procedures to be used to support Environmental Monitoring and Investigations program activities directly are presented in Table 42 , cross referenced to their source documents and the types of activities they typically will support.

\subsection{PROCEDURE APRROVALS AND CONTROL}

\subsubsection{Waste Management Technical Services}

The WMTS and EPH procedures that may be used to support nearfacility environmental monitoring sampling and monitoring activities are referenced in Table 4-2. Latest approved versions of all referenced procedures shall apply in all cases. Selected manuals include WMTS Operational Environmental Monitoring, HNF-IP-0718, Health Physics Technical Practices and Procedures, BHI-EE-02, Rev. O, Environmental Requirements, Section 7.0, HNF-MP-599, Project Hanford Quality Assurance Program Description, HNF-PRO-268, Control of Purchased Items and Equipment, and/or WMTS-QAM-001, Quality Assurance Manual, and WMNW-PCM-001, Procurement Manual. All procedures are available on request at the direction of EM\&I.

\subsubsection{Participant Contractor/Subcontractor Procedures}

As noted in section 3.4, participant contractor and/or subcontractor services may be procured with the concurrence of the EM\&I manager. Such procurement shall be subject to the applicable requirements of HNF-MP-599, Project Fanford Quality Assurance Program Description, and HNF-PRO-268, Control of Purchased Items and Equipment; and/or WMTS-QAM-001, Quality Assurance Manual, and WMNWPCM-001, Procurement Manual.

Whenever such services require procedural controls, use of WMTS procedures, or submittal of contractor procedures for WMTS review and approval before use, such requirements shall be included in the procurement document or work order. In addition to submitting analytical procedures, analytical laboratories shall be required to submit the current version of their $Q A$ plans. 
HNF-EP-0538-5

\subsection{PROCEDURE ADDITIONS AND CHANGES}

Additional procedures or changes to existing procedures that are necessary to accommodate unforeseen field situations may be authorized in accordance with section 4.0, "Program Verification" of WMTS-OEM-001, WMTS Operational Environmental Monitoring.

\subsection{SAMPLING SCHEDULE}

A Routine Operational Environmental Monitoring Schedule is issued annually. It includes the schedule of radiation surveys, sampling to be performed, and sampling frequency.

The Near-Field Monitoring team prepares the radiation survey and sampling schedules. The Near-Field Monitoring team shall approve any changes to the schedule, including temporary or one-time deviations, in accordance with WMTS-OEM-001, WMTS Operational Environmental Monitoring. 
HNF-EP-0 $538-5$

\subsection{SAMPLE CUSTODY}

All samples obtained during Environmental Monitoring and Investigations program activities shall be controlled as required by WMTS-OEM-001, WMTS Operational Environmental Monitoring, section 4, "Program Verification." These requirements apply as soon as the sample is introduced to the sample container.

Other requirements for specific samples are given in WMTS-OEM001, WMTS Operational Environmental Monitoring. These requirements shall ensure the maintenance of sample integrity and identification from receipt through completion of the analytical process.

Requirements for returning residual sample materials after analysis shall be defined in the procurement documentation or work orders to subcontractor or participant contractor laboratories. Analysis results shall be traceable to original samples through unique sample numbers or identification codes. All analyses results shall be controlled by the laboratory as quality assurance records, by the laboratory performing the analysis, as required by HNF-MP-599, Project Hanford Quality Assurance Program Description (and associated procedures) and HNF-PRO-210, Records Management Program Standards (and associated procedures). 
HNF-EP-0538-5

This page intentionally left blank.

6-2 


\subsection{CALIBRATION PROCEDURES}

Calibration of all WMTS equipment, whether in the existing inventory or purchased for near-facility environmental monitoring, shall be controlled as required by WMTS-QAM-001, Quality Assurance Manual.

Calibration and maintenance are the controlling factors in this system. Routine operational checks for WMTS field equipment shall be as defined in internal WMTS procedures; similar information shall be provided within WMTS-approved participant contractor or subcontractor procedures. The sampling and monitoring equipment used in this activity is controlled by the Component-Based Recall Calibration system (CBRCS) or another WMTS-approved system.

Calibration procedures can be made available under the direction of the EM\&I manager. 
HNF-EP-0538-5

This page intentionally left blank. 


\section{HNF-EP-0538- 5}

\section{0 ANALYTICAL PROCEDURES}

Analytical methods or procedures based on the reference methods identified in section 4.0 shall be selected or developed and approved before use in compliance with appropriate FPH procedure, work order, and/or procurement control requirements (Section 5.3.2).

All participating contractors or subcontractors quality-affecting records shall be retained in compliance with HNF-MP-599, Project Hanford Quality Assurance Program Description and/or WMTS-QAM-001, Quality Assurance Manual. All such documents will be made available on request at the direction of EM\&I. 
HNF-EP-0538-5

This page intentionally left blank. 
HNF-EP-0538-5

\subsection{MONITORING AND REPORTING CRITERIA}

The criteria for near-facility environmental sampling, monitoring, and reporting are identified in HNE-PRO-454, Inactive Waste sites, and HNE-PRO-455, Solid Waste Management. 
HNF-EP -0538-5

This page intentionally left blank. 


\subsection{DATA REDUCTION, VAIIDATION, AND REPORTING}

\subsection{DATA REDUCTION AND DATA PACKAGE PREPARATION}

Analytical laboratories shall be responsible for preparing both a report sumnarizing the analysis results and a detailed data package. The data package shall include information necessary to perform data validation to the extent indicated by the minimum requirements.

Data reporting requirements and data package content shall comply with the appropriate requirements of Test Methods for Evaluating Solid wastes, SW-846-1 (EPA 1992). These requirements shall be defined in work order or procurement documentation, subject to WMTS review and approval as noted in section 4.2 .

Data packages shall be prepared in legible, reproducible format; any changes must be made as single-line corrections in black, nonsoluble ink; changes must be initialed and dated.

Other supporting information (such as initial calibration data, reconstructed ion chromatographies, spectrograms, and raw data) need not be included in the submittal of individual data packages unless specifically requested by EM\&I.

The analytical laboratory shall retain all sample data and make it available for system or program audits at the request of WMTS EPA, the U.S. Department of Energy, Richland Operations Office (RL), WDOH representatives, or other regulatory agencies. The analytical laboratory shall retain such data through the duration of the authorization task order or for the period of their contractual statement of work, when it shall be turned over to the contract administrator for archiving.

The analytical laboratory's $Q A$ manager shall review and approve the completed data package before submittal for validation. The requirements of this section shall be included in procurement documentation or work orders, as appropriate, in compliance with the standard WMTS procurement control procedures referenced in section 3.0 .

\subsection{VALIDATION}

The EM\&I shall verify and validate completed data packages for radioactive operational environmental samples when requested. Analytical services (AS) may be requested to validate the completed data packages for hazardous or nonradioactive operational

environmental samples. Alternative sources may be used as directed by EM\&I. Regardless of the source of validation services, validation requirements shall be defined with WMTS-approved data validation procedures, which at a minimum shall require the following QC checks. 
For organic analyses, validation reports shall be prepared documenting QC checks as recommended in Laboratory Data Validation Functional Guidelines for Evaluating Organics Analyses (EPA 1988).

Eor inorganic analyses, validation reports shall be prepared documenting $\mathrm{QC}$ checks as recommended in Laboratory Data Validation Functional Guidelines for Evaluating Inorganics Analyses (EPA 1988b).

Validation procedures for radionuclides and other types of analyses shall include requirements for $Q C$ checks with similar levels of detail.

The level of confidence in the data resulting from the radiological analyses shall be estimated by analyzing blanks and spiked pseudosamples (EPA-designated environmental measurement laboratory program) and by comparing the resulting concentration estimates to the known concentrations in those samples. The precision of radionuclide analytical results shall be reported as a range, a variance, a standard deviation, a standard error, and/or a confidence interval. When selecting the data to be considered, outliers shall be excluded from the data only after investigation confirms that an error has been made in the sample collection, preparation, measurement, or data analysis process. As new data are received, they shall be compared to earlier data.

\subsection{FINAI REVIEW AND RECORDS MANAGEMENT CONSIDERATIONS}

The EM\&I will perform a final technical review of validation reports and supporting analytical data packages before submittal to the customer or inclusion in reports or technical memoranda. Records management practices shall comply with HNF-MP-599, Project Hanford Quality Assurance Program Description. 


\subsection{INTERNAI QUALITY CONTROI}

In general, analytical samples shall be subject to in-process quality control measures in both the field and the laboratory. The following minimum field quality control requirements apply to routine operational environmental monitoring samples. These requirements are adapted from those recommended by the EPA Office of Enforcement, as well as those of the research and development contractor, where practical. Radiological Control uses procedures described in HNE-IP0718 .

\subsection{SAMPIE QUALITY CONTROI}

The quality control of field samples is maintained using one or more of the following methods as appropriate.

- Replicates: repeated but independent determinations of the same sample.

- Blanks: a sample of the carrying agent (gas, liquid, or solid) normally used to selectively measure a material of interest that is subjected to the usual analytical procedures process to establish a baseline of background value. This value is then used to adjust or correct the routine analytical results.

- Duplicates: single sample taken, aliquoted alternately into two sets of sample containers for duplicate analysis.

- Splits: single sample taken, aliquoted alternately into two or more sets of sample containers, but will be sent to different laboratories; one sample will be sent to the primary laboratory, the others will be sent to an independent laboratory.

- Spiked Sample: a normal sample of material (gas, liquid, or solid) to which a known amount of some substance of interest is added. spiked samples are used to check on the accuracy of a routine analysis of the recovery efficiency of an analytical method.

\subsection{IABORATORY ANALYSES}

Near-facility environmental monitoring depends on the data received from analytical laboratories. A procedure verification program is vital to environmental sample analyses. This procedure verification effort consists of analytical standards, adherence to written sampling procedures, procedural audits, and record keeping.

The following companies whose services are controlled in accordance with procedures in HNF-MP-599, Project Hanford Quality Assurance Program Description, provide laboratory support to nearfacility environmental monitoring sampling program:

1. Offsite Laboratory. This laboratory analyzes selected 
environmental media samples.

2. Project Hanford Management Contract. The analytical laboratories analyze air samples and the sediment, water, and aquatic vegetation samples from the liquid disposal sites and the environmental soil, vegetation, and biota samples.

3. Radiation standards and Engineering at Pacific Northwest National Laboratory. The Calibration Laboratory at PNNL reads, tests, calibrates, and packages the thermoluminescent dosimeters.

4. Internal Laboratory Quality Control Programs. All laboratories maintain internal quality control programs that address practices such as:
a. Routine calibration of counting instruments
b. Routine source and background counts
c. Routine yield determination of radiochemical procedures
d. Replicate analyses to check precision
e. Analysis of quality control standards
f. Analysis of reagent blanks to verify chemical purity.

5. National standards Program. The laboratories performing the environmental analyses use standards traceable to the National Institute of standards and Technology, when available, to ensure the accuracy of radionuclide determinations.

Other requirements specific to laboratory analytical equipment calibration are included in section 7.0 . The minimum requirements of this section shall be invoked in procurement documents or work orders in compliance with standard FPH procedures as noted in section 5.3.2. The statement of work should be reviewed by the laboratory to ensure that the laboratory is capable of performing the work. 
HNF-EP-0538-5

\subsection{SYSTEM AUDITS}

Audits shall be performed to verify the quality of operation of one or more elements of the total measurement system. In the sense intended by QAMS-005/80 (EPA 1983), system audits involve a qualitative onsite evaluation of laboratories (or other organizational elements of the measurement system) for compliance with established $Q A$ program and procedure requirements. This also includes audits of individual facility sampling programs against those requirements in near-facility environmental monitoring.

The appropriate organization shall perform system audits; system audit requirements shall be implemented through the use of HNF-MP599, Project Hanford Quality Assurance Program Description, and HNFPRO-246, Management Assessments. Additional performance or system audits shall be conducted if specifically required by near-facility environmental monitoring, as a consequence of corrective action requirements, or if requested by $Q A$, RL, EPA, or WDOH.

Any discrepancies observed while evaluating performance audit results or during system audit surveillance activities that cannot be corrected immediately to the satisfaction of the investigator shall require a response and appropriate corrective action. All discrepancies shall be documented.

Environmental Monitoring and Investigations activities may be evaluated as part of a FPH facility or program audit in accordance with HNF-MP-599, Project Hanford Quality Assurance Program

Description, HNE-PRO-246, Management Assessments, and/or as part of a WMTS program audit in accordance with WMTS-QAM-001, Quality Assurance Manual, WMTS-QAP-001, Quality Assurance Procedures. 
HNF-EP-0538-5

This page intentionally left blank. 


\subsection{PREVENTIVE MAINTENANCE}

Equipment used in the field and laboratory that directly affect the quality of the analytical data shall be subject to preventive maintenance measures that ensure measurement systems have minimal downtime and can perform reliable measurements. Field equipment maintenance instructions shall be as defined by the approved procedures governing equipment use.

Laboratories shall be responsible for performing or managing the maintenance of their analytical equipment; maintenance requirements, spare parts lists, and instructions shall be included in individual methods or in laboratory $Q A$ plans, subject to WMTS review and approval as noted in Sections 3.3 and 4.2 . 
HNF-EP-0538-5

This page intentionally left blank. 
HNF-EP-0538-5

\subsection{DATA ASSESSMENT PROCEDURES}

Data from environmental media sampling and monitoring shall be assessed as required by near-facility environmental monitoring and appropriate statistical evaluation techniques that may be referenced therein. The laboratory first shall compile the analytical data, and validate it in compliance with the requirements established in the approved statement of Work. 
HNF-EP-0538-5

This page intentionally left blank. 


\subsection{CORRECTIVE ACTION}

Requests for corrective action required as a result of surveillance or audit activity shall be documented and dispositioned as required by HNF-MP-599, Project Hanford Quality Assurance Program Description, and HNE-PRO-298, Nonconforming Item Reporting and Control, HNF-PRO-52, Corrective Action Management, and WMTS-OEM-001, WMTS Operational Environmental Monitoring.

The EM\&I responsibilities for corrective action follow-up and resolution are contained in WMTS-OEM-001, WMTS Operational

Environmental Monitoring. Other measurement systems, procedures, or plan corrections that may be required as a result of routine review processes shall be resolved as required by governing procedures or shall be referred to EM\&I for resolution. Copies of all surveillance nonconformance, audit, and corrective action documentation shall be maintained on completion or closure by the surveillance/auditing organization. The project $Q A$ records location shall be specified by EM\&I. 
HNF-EP-0538-5

This page intentionally left blank. 
HNF-EP-0538-5

\subsection{QUALITY ASSURANCE REPORTS}

As stated in Sections 11.0 and 12.0 , Environmental Monitoring and Investigations program activities shall be assessed regularly by surveillance and auditing processes. Surveillance, nonconformance, audit, and corrective action documentation shall be considered QA records and shall be documented and dispositioned as stated in Section 15.0. Records management requirements applicable to subcontractors or participant contractors shall be defined in applicable procurement documents or work orders as noted in section 5.3 .2 . 
HNF-EP-0538-5

This page intentionally left blank. 
HNF-EP-0538-5

\subsection{REFERENCES}

10 CFR-835, "Occupational Radiation Protection" Code of Federal Regulations, as amended.

10CFR820, General Statement of Enforcement Policy, Code of Federal Regulations, as amended.

10CFR830.120, Quality Assurance Requirements, Code of Federal Regulations, as amended.

40 CFR 61, "National Emission Standards for Hazardous Air Pollutants," Code of Federal Regulations, as amended.

40 CFR 70, "Operating Permit Program," Code of Federal Regulations, as amended.

40 CFR 264, "Standards for Owners and Operators of Hazardous Waste Treatment, Storage, and Disposal Facilities," Code of Federal Regulations, as amended.

40 CFR 265, "Interim Status standards for Owners and operators of Hazardous Waste Treatment, Storage, and Disposal Facilities," Code of Federal Regulations, as amended.

40 CER 302, "Designation, Reportable Quantities, and Notification," Code of Federal Regulations, as amended.

APHA, 1985, Standard Methods for the Examination of Water and Wastewater, 16th edition, American Public Health Association, American Water Works Association, and Water Pollution Control Federation, Washington, D.C.

Comprehensive Environmental Response, Compensation and Liability Act of 1980, as amended, 42 USC 9601 et seq.

Diediker, I. P. 1999, statement of Work for Service Provided by the Waste Sampling and Characterization Facility for Effluent Monitoring, HNF-EP-0835-5, Waste Management Federal Services, Hanford, Inc., Richland, washington.

DOE, 1987, The Environmental Survey Manual, Appendix D, U.S. Department of Energy/Office of Environmental Audit, Washington, D.C.

DOE, 1990, General Environmental Protection Program, DOE order 5400.1, U.S. Department of Energy, Washington, D.C.

DOE, 1990, Environmental Protection, Safety, and Health Protection Information Reporting Requirements, DOE Order 5484.1, U.S. Department of Energy, Washington, D.C.

DOE, 1993, Radiation Protection of the Public and the Environment, DOE Order 5400.5, U.S. Department of Energy, washington, D.C.

DOE, 1991, Environmental Regulatory Guide for Radiological Effluent Monitoring and Environmental Surveillance, DOE/EH-0173T, U.S. Department of Energy, Washington, D.C.

DOE, 1999, Radioactive Waste Management, DOE Order 435.1,

$$
\text { 17-1 }
$$


HNF-EP-0538-5

U.S. Department of Energy, Washington, D.C.

DOE-RL, 1994, Environmental Monitoring Plan, DOE/RL-91-50, Rev. 1, U.S. Department of Energy, Richland Operations Office, Richland, Washington.

EPA, 1972, Handbook for Analytical Quality Control in Water and Wastewater Laboratories, U.S. Environmental Protection Agency, Washington, D.C.

EPA, 1977, Handbook for Analytical Quality Control in Radioanalytical Laboratories, EPA-600/7-77/088, U.S. Environmental Protection Agency, Washington, D.C.

EPA, 1979, Methods for Chemical Analysis of Water and Wastes, EPA-600/4-79-020, U.S. Environmental Protection

Agency/Environmental Monitoring and support Laboratory, Cincinnati, ohio.

EPA, 1982, Prescribed Procedures for the Measurement of Radioactivity in Drinking Water, EPA 600/4-80-032, U.S. Environmental

Protection Agency/Office of Exploratory Research,

Washington, D.C.

EPA, 1983, Interim Guidelines and Specifications for Preparation of Quality Assurance Project Plans, QAMS-005/80, U.S. Environmental Protection Agency/Office of Exploratory Research, Washington, D.C.

EPA, 1984, Eastern Environmental Radiation Facility (EERE) Radiochemistry Procedures Manual, EPA 520/5-84-006, U.S. Environmental Protection Agency, Washington, D.C.

EPA, 1988, Laboratory Data Validation Functional Guidelines for Evaluating Organics Analyses, Hazardous Site Evaluation Division, U.S. Environmental Protection Agency, Washington, D.C.

EPA, 1988b, Laboratory Data Validation Functional Guidelines for Evaluating Inorganics Analyses, Hazardous Site Evaluation Division, U.S. Environmental Protection Agency, Washington, D.C.

EPA, 1989, "USEPA Contract Laboratory Program Statement of work for Inorganic Analysis," Federal Register, Vol. 54, No. 13, Sample Management office, U.S. Environmental Protection Agency, Washington, D.C.

EPA, 1992, Test Methods for Evaluating Solid Wastes, SW-846, Third Edition, U.S. Environmental Protection Agency/office of Solid Waste and Emergency Response, Washington, D.C.

EPA, 1994, EPA Requirements for Quality Assurance Project Plans for Environmental Data Operations, EPA QA/R-5, U.S. Environmental Protection Agency, Washington, D.C.

HNF-EP-0528-3, NESHAP Quality Assurance Project Plan for Radioactive Air Emissions Data, Fluor Hanford. Richland, Washington.

HNF-EP-0835-5, Statement of Work for Services Provided by the Waste Sampling and Characterization Facility for the Effluent and 
Environmental Monitoring Program Calendar Year 1999, Fluor Hanford, Richland, Washington.

HNE-IP-0718, Health Physics Technical Practices and Procedures, Fluor Hanford. Richland, Washington.

HNF-MP-559, Project Hanford Quality Assurance Program Description, Fluor Hanford. Richland, Washington.

HNF-PRO-52, Corrective Action Management, Fluor Hanford. Richland, Washington.

HNF-PRO-210, Records Management Program Standards, Fluor Hanford. Richland, Washington.

HNF-PRO-222, Quality Assurance Records Standards, Fluor Hanford, Richland, Washington.

HNF-PRO-224, Document Control Program Standards, Fluor Hanford, Richland, Washington.

HNF-PRO-246, Management Assessment, Fluor Hanford. Richland, Washington.

HNF-PRO-261, Quality Assurance Program Plans, Fluor Hanford, Richland, Washington.

HNF-PRO-268, Control of Purchased Items and Services, Fluor Hanford. Richland, Washington.

HNF-PRO-298, Nonconforming Item Reporting and Control, Fluor Hanford. Richland, Washington.

HNF-PRO-450, Air Quality--Radioactive Emissions, Fluor Hanford, Richland, Washington.

HNF-PRO-454, Inactive Waste Sites, Fluor Hanford. Richland, Washington.

HNF-PRO-455, Solid Waste Management, Fluor Hanford. Richland, Washington.

HNF-PRO-490, Calibration Management Program, Fluor Hanford, Richland, Washington.

HNE-PRO-1892, Documentation of Radiological Surveys, Fluor Hanford, Richland, Washington.

HNF-PRO-3232, Evaluation for Down Posting Outdoor Contamination Areas, Fluor Hanford, Richland, Washington.

HNF-SD-CP-QAPR, Waste Sampling and Characterization Facility Quality Assurance Project Plan, Fluor Hanford, Richland, Washington.

Thomas, S. P., 1993, Services Provided by the 222-S Laboratory for Regulatory support, WHC-EP-0689, Westinghouse Hanford Company, Richland, Washington.

WAC 173-303, 1990, "Dangerous Waste Regulations," Washington Administrative Code, as amended. 
WAC 246-247, 1990, "Radiation Protection Standards," Washington Administrative Code, as amended.

WHC, 1991, A Guide for Preparing Hanford Site Eacility Effluent Monitoring Plans, WHC-EP-0438, Westinghouse Hanford Company, Richland, Washington.

WMTS-OEM-001, WMTS Operational Environmental Monitoring, Waste Management Technical Services, Richland, Washington.

WMNW-PCM-001, Procurement Manual, Waste Management Technical Services, Richland, Washington.

WMTS-QAM-001, Quality Assurance Manual, Waste Management Technical Services, Richland, Washington.

WMTS-QAPP-001, Quality Assurance Program Plan for Project Hanford Management Contract Work, Waste Management Technical Services, Richland, Washington. 
Number of copies

ONSITE

U.S. Department of Energy, Richland Operations office

E. M. Bowers

A2 -15

R. F. Brich

$\mathrm{K} 8-50$

P. F. Dunigan Jr.

A5 -58

J. B. Hall

A2 -15

R. G. McLeod

$\mathrm{HO}-12$

R. O. Puthoff

A $7-80$

H. M. Rodriguez

A5 -15

D. C. Ward

A2 -15

Public Reading Room

H2 -53

Bechtel Hanford, Inc.

R. J. Landon

J. G. Woolard

$\mathrm{HO}-02$

P. J. Woods

HO- 02

J. P. Zoric

S3-20

Environmental

X5-53

HO-O9

1

Fluor Hanford

D. G. Ranade

G1-37

Lockheed Martin Services, Inc.

Document Process Center A3-94

Central files

Pacific Northwest National Laboratory

R. L. Dirkes

R. W. Hanf

Hanford Technical Library

K6-75

$\mathrm{K} 6-75$

$\mathrm{P} 8-55$

Waste Management Hanford

L. P. Diediker (5)

G1-29 
HNF-EP-0538- 5

P. K. Brockman

J. J. Dorian (2)

J. A. Eacker

A. R. Johnson

B. M. Markes

S. M. Mckinney (10)

J. E. Meisner

R. M. Mitchell

D. J. Moak

M. F. Nicol

C. J. Perkins

J. M. Rodriguez

R. C. Roos
H1- 11

$\mathrm{H} 1-11$

H1-11

H5-26

H1-11

H1-11

H1-11

H1-11

H1-11

H1-11

H1-11

H1-11

H1-11 


\section{HNF-EP-0538-5}

This page intentionally left blank. 